\begin{tabular}{l|c|c}
\hline ISSN: 0001-5113 & ACTAADRIAT., & SHORT COMMUNICATION \\
AADRAY & $62(1): 111-116,2021$ & \\
\hline
\end{tabular}

\title{
Occurrence of juveniles Luvarus imperialis (Actinopterygii: Perciformes: Luvaridae) in the Strait of Sicily
}

\author{
Gianni INSACCO ${ }^{1 *}$, Bruno ZAVA² and Maria CORSINI-FOKA ${ }^{3}$ \\ ${ }^{1}$ Museo Civico di Storia Naturale, via degli Studi 9, 97013 Comiso (RG), Italy \\ ${ }^{2}$ Wilderness studi ambientali, via Cruillas 27, 90146 Palermo, Italy \\ ${ }^{3}$ Hellenic Centre for Marine Research, Institute of Oceanography, Hydrobiological Station of \\ Rhodes, Cos Street, 85100 Rhodes, Greece
}

"Corresponding author, e-mail: g.insacco@comune.comiso.rg.it

Two juveniles Luvarus imperialis, astrodermella stage, $97.4 \mathrm{~mm}$ and $90.6 \mathrm{~mm}$ in total length, were recorded on September 2016 and August 2017 respectively, the first caught by a bottom trawler off the south-eastern coast of Sicily, Strait of Sicily, Italy, the second found stranded on the beach in the nearby region. Biometrics data of this uncommon species are given and the occurrence of juvenile stages in the Mediterranean area is briefly discussed.

Key words: Luvarus imperialis; astrodermella stage; Sicily; Italy; Mediterranean Sea

\section{INTRODUCTION}

The perciform fish Luvarus imperialis Raf. 1810 , is the single species in the family Luvaridae. The luvar is an oceanic, mesopelagic and sometimes epipelagic species also found near the coasts, distributed in the temperate and tropical waters of the Atlantic, Indian and Pacific oceans (DOMINGUES et al., 2015; FROESE \& PAULY, 2019). It is known from scattered records also throughout the Mediterranean, from the west to the central and east, up to the Adriatic and Ionian seas, the Aegean Sea up to the Dardanelles Strait, the Mediterranean coasts of Turkey and also southern Mediterranean, in Algerian, Tunisian and Libyan waters (BAUCHOT, 1987; BRADAI et al., 2004; IRMAK \& ALPARSLAN, 2008; RELINI \& LANTERI, 2010; LIPEJ \& DULČIĆ, 2010; PAPACONSTANTINOU, 2014; BILECENOĞLU et al.,
2014; GEROVASILEIOU et al., 2017; ELBARAASI et al., 2019). In addition, a stranded adult has been reported from Porto Vecchio, Corse, France, in July 2012 (https://www.corsematin.com). The luvar is not jet listed among the ichthyofauna of the eastern Levant (GOLANI et al., 2006; BARICHE, 2012; AKEL \& KARACHLE, 2017; ALI, 2018; FROESE \& PAULY, 2019).

The species L. imperialis was observed and drawn for the first time by Costantino Samuele Rafinesque Schmaltz; the type specimen of this fish was found stranded on the beach of Solanto (Palermo) in $15^{\text {th }}$ June 1808; it was five feet long $(152.4 \mathrm{~cm})$ and weighed 110 Sicilian "rotoli" (about 87 kilograms) (RAFINESQUE, 1810).

It is a large species reaching $200 \mathrm{~cm}$ in total length, commonly 60 to $150 \mathrm{~cm}$, and $140 \mathrm{~kg}$ in weight and it feeds mainly on jellyfish, ctenophores, salps and other gelatinous planktonic 
animals (COLE, 2010; FROESE \& PAULY, 2019). Distinctive characters in the adult are: body stout, high and compressed, rising steeply forehead, blunt-snouted, eyes small and positioned down, at the mouth level; dorsal fin beginning at the middle of the back, anal opposite to the dorsal; pectoral long; ventral fin rudimentary; caudal fin falcate; a prominent keel on the caudal peduncle and two small keels at the caudal fin base; teeth absent; color back blue, belly white with a pink stripe between them; all fins pink; meristics: dorsal rays 12-14; anal rays, 13-14; pectoral rays, 18; ventral 1 (BOUCHOT, 1987; GOLANI et al., 2006).

Juveniles differ significantly from adults mainly in that the median fins are longer, the dorsal starting at the nape level (22-24 rays), anal fin 15-18 rays, the mouth toothed and the body and fins black-spotted (BOUCHOT, 1987; FROESE \& PAULY, 2019). They go through a hypermetamorphosis consisting of three larval stages: "hystricinella" (from 0.5 to $2.6 \mathrm{~cm}$ ), "astrodermella" (from 2.6 to $40 \mathrm{~cm}$ ), and "luvarella" (from 40 to $100 \mathrm{~cm}$ ) during which evident changes appear mainly in the shape of body and head, in the number of fin rays and in the colour (ROULE, 1924; BINI, 1968; TORTONESE, 1975).

Very little is known about the life history of the luvar in the Mediterranean (DULČIĆ et al., 1999). In this work the findings of two "astrodermella" stage samples of L. imperialis are described and their measurements are given, while the occurrence of juvenile stages in the Mediterranean basin is briefly reviewed.

\section{MATERIAL AND METHODS}

Two specimens of Luvarus imperialis, "astrodermella" stage, were recently caught in the waters off Scoglitti, Ragusa, southeast Sicily, Italy. The first, specimen A (Fig. 1a), was collected on $9^{\text {th }}$ September 2016 by professional fishermen using a traditional trawl net (coordinates $36^{\circ} 48^{\prime} 11^{\prime}$ N, $14^{\circ} 19^{\prime} 22^{\prime}$ 'E), on a sandy bottom at about $100 \mathrm{~m}$ depth. The specimen was caught during the ascent phase of the fishing net in the water column, jointly with some Atlantic horse mackerels, Trachurus trachurus
(Linnaeus, 1758). The second sample, specimen B (Fig. 1b), was stranded on $24^{\text {th }}$ August 2017 on the beach of Contrada Cammarana, Scoglitti (coordinates 3652'44'N, 14²6'19'"E). The fresh specimens were measured, weighed, photographed and identified according to LOZANO CABO (1945) and TYLER et al. (1989). Later, the samples were preserved in $10 \%$ formalin solution at the fish collection of the Museo Civico di Storia Naturale di Comiso (Province of Ragusa) with the inventory numbers MSNC-4533 and MSNC-4588, for specimen A and B respectively.

\section{RESULTS}

The meristic data for both "astrodermella" $L$. imperialis specimens A and B were: dorsal fin rays 23; anal fin rays 18 ; pectoral fin rays 18 ; pelvic fin rays 5. Morphometrics and weight are given in Table 1.
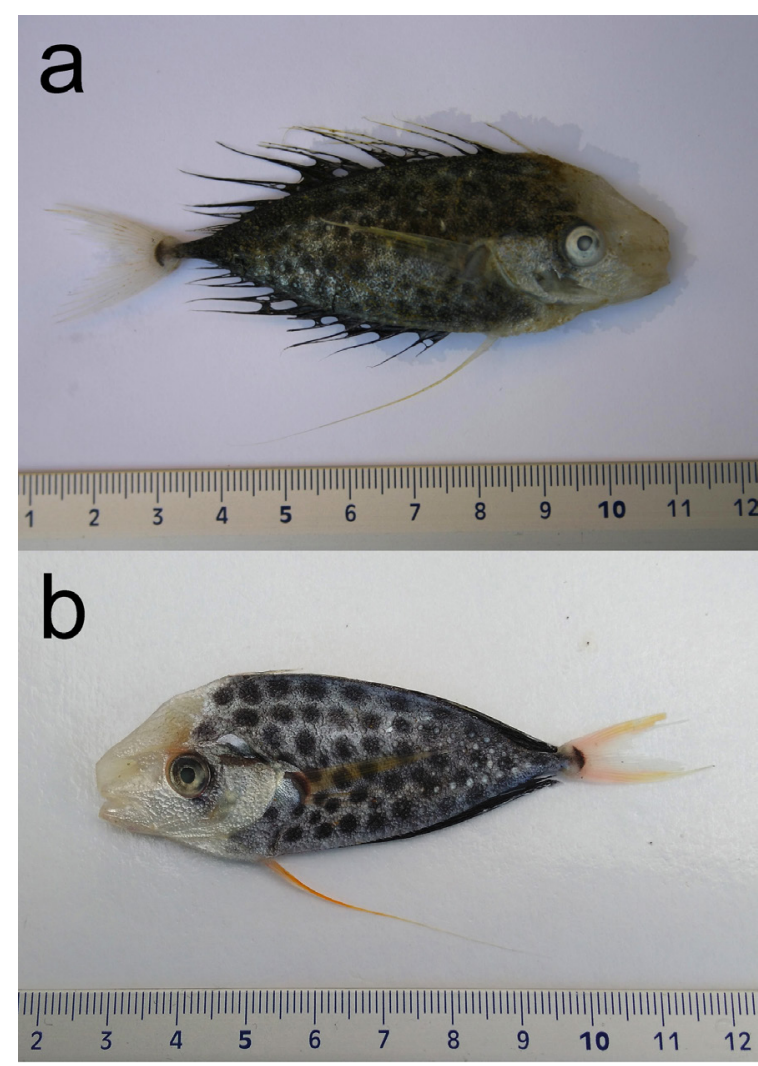

Fig. 1. Luvarus imperialis, astrodermella stage, caught in the Strait of Sicily, Italy. (a) Specimen, preserved (MSNC-4533), summer 2016; (b) Specimen, fresh (MSNC-4588), summer 2017 
Table 1. Morphometric measurements ( $\mathrm{mm}$ ) and weight $(\mathrm{g})$ of the two Luvarus imperialis specimens, "astrodermella" stage, caught off southeast Sicily, Italy.

\begin{tabular}{lcc}
\hline & Specimen A & Specimen B \\
\hline Total length & 97.4 & 90.6 \\
Fork length & 89.1 & 76.1 \\
Standard length & 76.9 & 74.8 \\
Predorsal length & 19.8 & 19.4 \\
Preanal length & 33.9 & 28.0 \\
Preventral length & 25.0 & 23.8 \\
Prepectoral length & 27.4 & 26.8 \\
Dorsal fin length & 49.4 & 47.7 \\
Anal fin length & 39.3 & 36.0 \\
Pectoral fin length & 23.8 & 24.9 \\
Ventral fin length & 47.0 & 44.8 \\
Caudal fin length & 23.4 & 20.8 \\
Body depth max. & 28.0 & 27.0 \\
Body depth min. & 19.0 & 23.0 \\
Body depth at & 4.4 & 2.3 \\
caudal peduncle & & \\
Head length & 28.5 & 26.2 \\
Orbital diameter & 6.5 & 5.8 \\
Preorbital length & 13.0 & 11.2 \\
Postorbital length & 15.0 & 10.6 \\
Weight & 16 & 7 \\
\hline & & \\
\hline
\end{tabular}

Description (Fig. 1a, b): body compressed, oblong; large head with a profile lightly concave; eyes placed beyond and over the level of the small mouth. Dorsal fin long begins at nape level and terminates at the caudal peduncle, its last rays reaching the base of caudal fin; anal opposite to the dorsal, less long. Ventral fin very long, reaching the end of anal fin base. Caudal fin semilunar. Ventral fin long, overpasses the middle of anal fin base. Color of fresh specimen (Fig. 1b): head silvery-whitish; background of the remaining body silvery with large dark-black roundish spots, similar to stars (thus the etymology of the name "astrodermella"); dorsal and anal fins dark; pectoral and ventral fins orange, caudal fin orange-pink on upper and lower lobe, transparent in the center.

Meristics, morphometric measurements and color agree with the juvenile stage "astrodermella" (122 mm total length) described in ROULE
(1924) for L. imperialis phase A and reported in LOZANO CABO (1945), apart the number of dorsal fin rays (22 vs 23 in our samples). On the other hand, the number of 23 dorsal fin rays has been reported for "astrodermella" (238 $\mathrm{mm}$ total length) by DULČIĆ et al. (1999) and it is included in the range of 22-24 rays reported for juveniles by BAUCHOT (1987).

\section{DISCUSSION}

The species Luvarus imperialis is rarely present in the Sicilian fish markets and it is considered a by-catch of tuna and swordfish fisheries (CANNIZZARO et al., 2000). It is sold fresh and its flesh is generally highly appreciated. Captures happen generally during the months of May, June and July; about two dozen of individuals were landed in the last two years for the whole Sicilian region (First author, personal data); almost all the captures came from driftnets, a few from long-lines and gillnets. It should be noted that at the fish market of Scoglitti village (Ragusa), in the area under study, the only specimen landed in the last decade was an adult female of about $22 \mathrm{~kg}$ caught with a trammel net in May 2009. According to COLE (2010), the species reproduces in late spring and summer in the Mediterranean. Luvar larvae and juveniles are also very rarely collected in the basin. In Italy, HELDT (1932), in his accurate review, mentioned the occurrence of one "hystricinella" stage individual from the Strait of Messina, one "astrodermella" stage sample from the Messina region, larvae and one "luvarella" from the Gulf of Naples; another "astrodermella" (290 mm) was collected at Finale Ligure, Ligurian Sea (CAMPI, 1963 in BINI, 1968 and in COSTA, 1991). One luvar larva was collected in 2008 at Cape Passero, southeastern Sicily (AGUILAR \& LASTRA, 2009), not far from the area under study. In other Mediterranean regions, one luvar "hystricinellaphase" and one "astrodermella-phase" were collected in June and December 1994 respectively, in the eastern central Adriatic Sea, Croatia (DULČIĆ et al., 1999). Various "astrodermellaphase" samples have been reported in the past from Balearic Islands and the waters of Cata- 
luña (GRAU et al., 2000) and larvae of the species were reported more recently (2006-2008) in the waters of the Balearic Islands (TORRES et al., 2011). Samples of the first two early life stages of L. imperialis are also listed for Nice, France (HELDT, 1932).

In the present work, the findings of L. imperialis at "astrodermella" stage are documented for the first time from the waters of southeast Sicily. These findings improve the knowledge on the distribution of juveniles of this species in the Mediterranean Sea and add data on its early life stages, considered that these juvenile forms were not reported for over ten years in the whole basin. The hydrodynamic features of the Sicilian Channel create suitable conditions for spawning and nursery of early life stages of many fish species, in particular towards the southeast end of the Sicilian coast (LAFUENTE et al., 2002; AGUILAR \& LASTRA, 2009; CONSOLI et al., 2016). The occurrence of juveniles here described and the finding of larvae in the nearby region (AGUILAR \& LASTRA, 2009) could indicate that the area under study may be a growing ground for this species uncommon to the Mediterranean Sea.

\section{REMARK}

After the revision of the present manuscript, Authors were informed about the collection of a third astrodermella sample, on 18th August 2020 at Costa Viola, Reggio Calabria, Italy (38²2'14.79'N, 1550'56.85'”. (Emilia Fulgido, pers. comm.). The sample was photographed and released.

\section{ACKNOWLEDGEMENTS}

We are grateful to Giovanni Penna and his brothers Salvatore, Vincenzo and Claudio (Scoglitti, Ragusa), owners of the vessel "La Madonnina 1PO1088" and to Davide Ciravolo (Vittoria, Ragusa) for providing prompt information on the two findings described in the present work. We warmly thank also Dr. Emilia Fulgido, Reggio Calabria, for informing us about the recent collection of the third specimen mentioned in this work.

\section{REFERENCES}

AgUilar, R. \& P. LASTRA. 2009. Bluefin Tuna Larval Survey: 2008 Oceana-MarViva Mediterranean Project Report, 76 pp.

AKEL, E.H.Kh. \& P.K. KARACHLE. 2017. The Marine Ichthyofauna of Egypt. Egypt. J. Aquat. Biol. Fish., 21 (3): 81-116.

ALI, M. 2018. An updated Checklist of Marine fishes from Syria with an emphasis on alien species. Mediterr. Mar. Sci., 19 (2): 388-393. DOI: $10.12681 / \mathrm{mms} .15850$

BARICHE, M. 2012. Field identification guide to the living marine resources of the Eastern and Southern Mediterranean. FAO Species Identification Guide for Fishery Purposes. FAO. Rome, $610 \mathrm{pp}$.

BAUCHOT, M.-L. 1987. Poissons osseux. In: W. Fischer, M.-L. Bauchot \& M. Schneider (Editors). Fiches FAO d'identification des espèces pour les besoins de la pêches. (Révision 1). Méditerranée et Mer Noire. Zone de pêche 37. Vol. 2: Vertébrés. FAO. Rome, pp. 891-1422.

BILECENOĞLU, M., M. KAYA, B. CIHANGIR \& E. ÇIÇEK. 2014. An updated checklist of the marine fishes of Turkey. Turk. J. Zool., 38: 901-929. DOI: 10.3906/zoo-1405-60

BINI, G. 1968. Atlante dei pesci delle coste italiane. Vol. VI. Osteitti. Mondo Sommerso Publishers. Milano, 177 pp.

BRADAI, M.N., J.-P. QUIGNARD, A. BOUAIN, O. JARBOUI, A. OUANNES-GHORBEL, L. BEN ABDALLAH, J. ZAOUALI \& S. BEN SALEM. 2004. Ichtyofaune autochtone et exotique des côtes tunisiennes: recensement et biogéographie. Cybium, 28 (4): 315-328.

CAMPI, A. 1963. Elenco di catture di interessanti forme ittiche nelle acque del Finalese (Savona). Natura, 64 (1), 8-10.

CANNIZZARO, L., G. BONO, P. RIZZO, A. POTOSHI \& A. CELESTI. 2000. Diversifying fishing effort 
in Sicilian fisheries: the case of Fish Aggregating Devices (FADs). In: J.-Y. Le Gall, P. Cayré \& M. Taquet (Editors). Proceedings of the Colloquium Caraibe-Martinique Pêche thonière et dispositifs de concentration de poissons. Trois-Îlets, 15-19 October 1999, IFREMER, pp. 449-464. (https://archimer. ifremer.fr/doc/00042/15299/)

COLE, K.S. (EDITOR). 2010. Reproduction and sexuality in marine fishes: patterns and processes. University of California Press. Berkley, $432 \mathrm{pp}$.

CONSOLI, P., V. ESPOSITO, P. BATTAGLIA, C. ALTOBELLI, P. PERZIA, T. ROMEO, S. CANESE \& F. ANDALORO 2016. Fish Distribution and habitat complexity on banks of the Strait of Sicily (Central Mediterranean Sea) from RemotelyOperated Vehicle (ROV) Explorations. PLoS ONE, 11 (12): e0167809. DOI:10.1371/journal.pone.0167809

COSTA, F. 1991. Atlante dei pesci dei mari italiani. Mursia. Milano, 517 pp.

DOMINGUES, R.R., S. MONTEALEGRE-QUIJANO, J.M.R. SOTO \& A.F. AMORIM. 2015. Five new records of Luvarus imperialis (Acanthuroidei: Luvaridae) in the south-west Atlantic Ocean. J. Fish Biol., 86: 1203-1208. DOI:10.1111/ jfb. 12629

DULČIĆ, J., I. JARDAS \& I. KAČIĆ. 1999. New records of the early life history stages of louvar, Luvarus imperialis Rafinesque, 1810, from the eastern Adriatic. Ann. Ser. Hist. Nat., 9: 3-8.

ELBARAASI, H., B. ELABAR, S. ELAABIDI, A. BASHIR, O. ELSILINI, E. SHAKMAN \& E. AZZURRO 2019. Updated checklist of bony fishes along the Libyan coast (southern Mediterranean Sea). Mediterr. Mar. Sci., 20 (1): 90-105. DOI: $10.12681 / \mathrm{mms} .15570$

FROESE, R. \& D. PAULY (EDITORS). 2019. FishBase. World Wide Web electronic publication. www.fi shbase.org. Accessed on 20 July 2019.

GEROVASILEIOU, V., E.H.KH. AKEL, O. AKYOL, G. ALONGI, F. AZEVEDO, N. BABALI, R. BAKIU, M. BARICHE, A. BENNOUI, L. CASTRIOTA, C.C. CHINTIROGLOU, F. CROCETTA, A. DEIDUN, S. GALINOU-MITSOUDI, I. GIOVOS, M. GÖKOĞLU,
A. GOLEMAJ, L. HADJIOANNOU, J. HARTINGEROVA, G. INSACCO, S. KATSANEVAKIS, P. KLEITOU, J. KORUN, L. LIPEJ., M. MALEGUE, N. MICHAILIDIS, A. MOUZAI TIFOURA, P. OVALIS, S. PETOVIĆ, S. PIRAINO, S.I. RIZKALLA, M. ROUSOU, I. SAVVA, H. ŞEN, A. SPINELLI, K.G. VOUGIOUKALOU, E. XHARAHI, B. ZAVA \& A. ZENETOS. 2017. New Mediterranean Biodiversity Records (July 2017). Mediterr. Mar. Sci., 18 (2): 355-384. DOI: 10.12681/mms.2068

GOLANI, D., B. ÖZTÜRK \& N. BAŞUSTA. 2006. Fishes of the eastern Mediterranean. Turkish Marine Research Foundation. Istanbul, 259 pp.

GRAU, A., E. MASSUTÍ, F. RIERA, A. QUETGLAS \& A.M. GRAU. 2000. First record of an adult specimen of Luvarus imperialis Rafinesque, 1810 in Balearic waters (Western Mediterranean). Anatomical and biological considerations. Boll. Soc. Hist. Nat. Balears, 43: 91-98.

HELDT, H. 1932. Luvarus imperialis Raf. Addition à la faune ichthyologique tunisienne. Considérations anatomique et biologique. Notes Stn. Océanogr. Salammbô, 47: 1-27

IRMAK, E. \& M. ALPARSLAN. 2008. A new record for Çanakkale (Turkey) Strait: Luvarus imperialis Rafinesque, 1810 (Pisces: Luvaridae). Journal of FisheriesSciences.com 2 (3): 506-509. DOI: 10.3153/jfscom.mug.200747 (Turkish, English Abstract)

LAFUENTE, J.G., A. GARCÍA, S. MAZZOLA, L. QUINTANILLA, J. DELGADO, A. CUTTITA \& B. PATTI. 2002. Hydrographic phenomena influencing early life stages of the Sicilian Channel anchovy. Fish. Oceanogr., 11 (1): 31-44. DOI: 10.1046/j.1365-2419.2002.00186.x

LIPEJ, L. \& J. DULČIĆ. 2010. Checklist of the Adriatic Sea Fishes. Zootaxa, 2589: 1-92.

LOZANO CABO, F. 1945. Nota sobre la presencia de estados juveniles de Luvarus imperialis Rafinesque, en las costas de Baleares y Cataluña. Bol. R. Soc. Esp. Hist. Nat. 43: 353-364.

PAPACONSTANTINOU, C. 2014. Fauna Graeciae. An updated checklist of the fishes in the Hellenic Seas. K. Kapiris, P.K. Karachle \& A. Zenetos (Editors). Monographs on Marine Sciences 7. HCMR. Athens, 340 pp. 
RAFINESQUE, C.S. 1810. Caratteri di alcuni nuovi generi e nuove specie di animali e piante della Sicilia, con varie osservazioni sopra i medesimi. Stampe di Sanfilippo. Palermo, $105 \mathrm{pp}$.

RELINI, G. \& L. LANTERI. 2010. Osteichthyes. Biol. Mar. Mediterr., 17 (suppl. 1): 649-674.

ROULE, L. 1924. Étude sur l'ontogénèse et la croissance avec hypermètamorphose de Luvarus imperialis Raf. (Poisson rapportè à l'ordre des Scombriformes). Ann. Inst. Océanogr. Monaco (n.s.), 1: 119-157.

TORRES, A.P., P. REGLERO, R. BALBIN, A. URTIZBEREA \& F. ALEMANY. 2011. Coexistence of larvae of tuna species and other fish in the surface mixed layer in the NW Mediterra- nean. J. Plankton Res., 33 (12): 1793-1812. DOI: $10.1093 /$ plankt/fbr078

TORTONESE, E. 1975. Osteichthyes (Pesci ossei), II. Fauna d'Italia, 11. Calderini. Bologna, $636 \mathrm{pp}$.

TYLER, J.C., G.D. JOHNSON, I. NAKAMURA \& B.B. COLLETTE. 1989. Morphology of Luvarus imperialis (Luvaridae), with a phylogenetic analysis of the Acanthuroidei (Pisces). Smithson. Contrib. Zool., 485: 1-78.

\section{ONLINE RESOURCES}

https://www.corsematin.com/article/porto-vecchio/un-luvarus-imperialis-seteint-sur-lescotes-de-porto-vecchio (Accessed online on 15 September 2019)

Received: 12 January 2020

Accepted: 13 January 2021

\title{
Pojava mlađi pjevčine pučinke Luvarus imperialis (Actinopterygii: Perciformes: Luvaridae) u Sicilijskom tjesnacu
}

\author{
Gianni INSACCO*, Bruno ZAVA i Maria CORSINI-FOKA \\ *Kontakt, e-pošta: g.insacco@comune.comiso.rg.it
}

\section{SAŽETAK}

Dva primjerka mlađi Luvarus imperialis, (stadij astrodermella) ukupnih dužina 97,4 mm i 90,6 mm, zabilježena su u rujnu 2016., odnosno kolovozu 2017. godine. Prvi primjerak je ulovljen koćom na jugoistočnoj obali Sicilije, Sicilijski tjesnac, Italija. Drugi primjerak je pronađen na plaži u obližnjoj regiji.

U ovom radu, autori navode biometrijske podatke ove neobične vrste i ukratko se raspravlja o pojavi mlađih u mediteranskom području.

Ključne riječi: Luvarus imperialis; astrodermella; mlađ; Sicilija; Italija; Sredozemno more 